\title{
Synthesis of Iridium Pyridinyl N-Heterocyclic Carbene Complexes and Their Catalytic Activities on Reduction of Nitroarenes
}

\author{
Chao-Yu Wang, Ching-Feng Fu, Yi-Hong Liu, Shei-Ming Peng, and Shiuh-Tzung Liu* \\ Department of Chemistry, National Taiwan University, Taipei 106, Taiwan
}

Received February 21, 2007

Coordination of iridium(l) metal ions with a pyridinyl imidazol-2-ylidene ligand (py $\left.\mathbf{N}^{\wedge} \mathbf{C}-\mathbf{R}\right)[R=$ Me, mesityl $(2,4,6$ trimethylphenyl)] that processes bulky substituents has been investigated. The iridium carbene complexes $\left[\left(C-\right.\right.$ pyN $\left.\left.{ }^{\wedge} \mathbf{C}-\mathbf{R}\right) \mid \mathrm{rCl}(\mathrm{COD})\right](\mathrm{COD}=1,5$-cyclooctadiene) are prepared via transmetalation from the corresponding silver carbene complexes. Upon the abstraction of chloride, the chelation of $p y \mathbf{N}^{\wedge} \mathbf{C}$ becomes feasible, resulting in the formation of [C,N-(pyN/ $\left.\left.\mathbf{N}^{\wedge}-\mathbf{R}\right) \operatorname{Ir}(\mathrm{COD})\right]\left(\mathrm{BF}_{4}\right)(4)$. The coordinated $\mathrm{COD}$ of complex 4 can be replaced by carbon monoxide to yield the corresponding carbonyl species $\left[C, N-\left(p^{\prime} N^{\wedge} C-R\right) \operatorname{Ir}(C O)_{2}\right]\left(B_{4}\right)$. The labile nature of the pyridinyl nitrogen donor is readily replaced by acetonitrile, as is evidenced by the NMR study. All iridium complexes show catalytic activity on the hydrogen-transfer reduction of carbonyl and nitro functionalities. By manipulation of the reaction conditions, the iridium-catalyzed reduction of nitroarenes can selectively provide aniline or azo compounds as the desired product.

\section{Introduction}

In recent years, the use of $\mathrm{N}$-heterocyclic carbenes as ligands for transition-metal ions in catalysis has increased significantly because of the effect of their strong $\sigma$-donor nature on the stabilization of metal ions. ${ }^{1}$ Among the various metal ions, applications of the iridium carbene complexes in homogeneous catalysis have also been reported. ${ }^{2-9}$ It is known that $\mathrm{N}$-heterocyclic carbeneiridium complexes can catalyze the Oppenauer-type oxidation, ${ }^{2}$ hydrogen-transfer

* To whom correspondence should be addressed. E-mail: stliu@ntu.edu.tw. Fax: (8862)23636359.

(1) For a recent review, see: (a) Herrmann, W. A. Angew. Chem., Int. Ed. 2002, 41, 1290. (b) Crudden, C. M.; Allen, D. P. Coord. Chem. Rev. 2004, 248, 2274. (c) Cavell, K. J.; McGuinness, D. S. Coord. Chem. Rev. 2004, 248, 671. (d) Bourissou, D.; Guerret, O.; Gabbai, F. P.; Bertrand, G. Chem. Rev. 2000, 100, 39. (e) Peris, E.; Crabtree, R. H. C. R. Chim. 2003, 6, 33. (f) Arduengo, A. J. Acc. Chem. Res. 1999, 32, 913. (g) Cesar, V.; Bellemin-Laponnaz, S.; Gade, L. H. Chem. Soc. Rev. 2004, 33, 619. (h) Reddy, R. K.; Liu, S.-T. Chem. Soc. Rev. 1999, 28, 315 and references cited therein.

(2) Hanasaka, F.; Fujita, K.; Yamaguchi, R. Organometallics 2005, 25, 4643 and references cited therein.

(3) (a) Albrecht, M.; Miecznikowski, J. R.; Samuel, A.; Faller, J. W.; Crabtree, R. H. Organometallics 2002, 21, 3596. (b) Miecznikowski, J. R.; Crabtree, R. H. Organometallics 2004, 23, 629. (c) Hahn, F. E.; Holtgrewe, C.; Pape, T.; Martin, M.; Sola, E.; Oro, L. A. Organometallics 2005, 24, 2203. (d) Seo, H.; Kim, B. Y.; Lee, J. H.; Park, H.-J.; Son, S. U.; Chung, S. Y. K. Organometallics 2003, 22, 4783. (e) Herrmann, W. A.; Baskakov, D.; Herdtweck, E.; Hoffmann, S. D.; Bunlaksananusorn, T.; Rampf, F.; Rodefeld, L. Organometallics 2006, 25, 2449.

(4) Mas-Marza, E.; Peris, E.; Castro-Rodriguez, I.; Meyer, K. Organometallics 2005, 24, 3158.

10.1021/ic070330l CCC: $\$ 37.00$ C 2007 American Chemical Society Published on Web 06/15/2007 reduction of carbonyl compounds, ${ }^{3}$ cyclization of alkynylcarboxylic acids, ${ }^{4}$ hydrogenation of olefins, ${ }^{5}$ hydrosilylation, ${ }^{6}$ hydroamination, ${ }^{7} \mathrm{C}-\mathrm{H}$ activation, ${ }^{8}$ and bornylation. ${ }^{8}$ However, to our knowledge, the use of iridium carbene complexes for catalytic reduction of nitro compounds has not been reported before.

Hydrogenation of functionalized nitrobenzenes produces anilines, which are important intermediates for the manufacture of a variety of agrochemicals, pharmaceuticals, dyes, and pigments. Reduction of nitro compounds can be carried out in the gas or liquid phase by using metal catalysts. ${ }^{10}$

(5) (a) Lee, H. M.; Jiang, T.; Stevens, E. D.; Nolan, S. P. Organometallics 2001, 20, 1255. (b) Vazquez-Serrano, L. D.; Owens, B. T.; Buriak, J. M. Chem. Commun. 2002, 2518. (c) Perry, M. G.; Cui, X.; Powell, M. T.; Hou, D.-R.; Reibenspies, J. H.; Burgess, K. J. Am. Chem. Soc. 2003, 125, 113. (d) Nanchen, S.; Pfaltz, A. Chem.-Eur. J. 2006, 4550. (e) Baskakov, D.; Herrmann, W. A.; Herdtweck, E.; Hoffmann, S. D. Organometallics 2007, 26, 626 and references cited therein.

(6) (a) Chianese, A. R.; Crabtree, R. H. Organometallics 2005, 24, 4432. (b) Mas-Marza, E.; Poyatos, M.; Sanau, M.; Peris, E. Inorg. Chem. 2004, 43, 2213. (c) Vicent, C.; Viciano, M.; Mas-Marzá, E.; Sanaú, M.; Peris, E. Organometallics 2006, 25, 3713.

(7) Field, L. D.; Messerle, B. A.; Vuong, K. Q.; Turner, P. Organometallics 2005, 24, 4241.

(8) (a) Corberan, R.; Sanau, M.; Peris, E. J. Am. Chem. Soc. 2006, 128, 3974. (b) Frey, G. D.; Rentzsch, C. F.; von Preysing, D.; Scherg, T.; Muehlhofer, M.; Herdtweck, E.; Herrmann, W. A. J. Organomet. Chem. 2006, 691, 5725.

(9) Imlinger, N.; Mayr, M.; Wang, D.; Wurst, K.; Buchmeiser, M. R. Adv. Synth. Catal. 2004, 346, 1836.

(10) Ragaini, F.; Cenini, S.; Gallo, E.; Caselli, A.; Fantauzzi, S. Curr. Org. Chem. 2006, 10, 1479.

Inorganic Chemistry, Vol. 46, No. 14, 20075779 
However, hydrogenation of aromatic nitro compounds poses problems, particularly for those with other reducible groups in the reaction. Alternatively, the hydrogen-transfer reduction offers a promising solution because of its selectivity. ${ }^{10}$ Herein, we report the preparation and characterization of a series of new pyridinylcarbene (denoted as $\mathbf{p y N}^{\wedge} \mathbf{C}-\mathbf{R}$ ) iridium(I) complexes as well as their catalytic activities toward the hydrogen-transfer reduction of nitroarenes under mild reaction conditions.

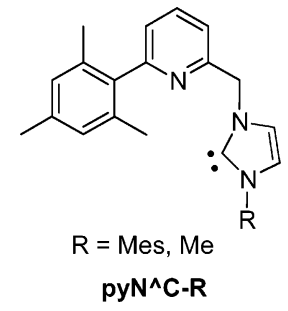

\section{Experimental Section}

General Information. Nuclear magnetic resonance (NMR) spectra were recorded in $\mathrm{CDCl}_{3}$ or acetone- $d_{6}$ on either a Bruker AM-300 or AVANCE 400 spectrometer. Chemical shifts are given in parts per million relative to $\mathrm{Me}_{4} \mathrm{Si}$ for ${ }^{1} \mathrm{H}$ and ${ }^{13} \mathrm{C}\left\{{ }^{1} \mathrm{H}\right\}$ NMR. IR spectra were measured on a Nicolet Magna-IR 550 spectrometer (Series II) as $\mathrm{KBr}$ pellets, unless otherwise noted.

All reactions and manipulations were performed under a dry nitrogen atmosphere. Tetrahydrofuran was distilled under nitrogen from sodium benzophenone ketyl. Dichloromethane was dried over $\mathrm{CaH}_{2}$ and distilled under nitrogen. Other solvents were degassed before use. Chemicals were purchased from a commercial source and used without further purification. The preparation methods of (6-mesitylpyridin-2-yl)methanol and complex $\mathbf{2 b}$ are described in the literature. ${ }^{11 \mathrm{a}}$

1-(6-Mesityl-2-picolyl)-3-methylimidazolium Bromide (1a). A solution of (6-mesitylpyridin-2-yl)methanol $(1.03 \mathrm{~g}, 4.53 \mathrm{mmol})$ in dichloromethane $(20 \mathrm{~mL})$ was cooled in an ice bath. Phosphorus tribromide $(1.2 \mathrm{~mL}, 12.8 \mathrm{mmol})$ was slowly added to the above solution, and the resulting solution was stirred at room temperature overnight. Water $(5 \mathrm{~mL})$ was then added to quench the excess of $\mathrm{PBr}_{3}$, and the solution was neutralized by sodium bicarbonate. The organic portion was separated and dried over magnesium sulfate. To this solution was added methylimidazole $(0.4 \mathrm{~g}, 4.9 \mathrm{mmol})$. The mixture was heated to reflux for $12 \mathrm{~h}$, and the desired product precipitated as a white solid from the solution. The solid was collected and recrystallized from alcohol to give the desired bromide as a white powder (88\%). ${ }^{1} \mathrm{H}$ NMR $\left(400 \mathrm{MHz}, \mathrm{CDCl}_{3}\right): \delta 10.36$ (s, 1H), 7.75-7.69 (m, 2H), 7.52-7.50 (m, 2H), $7.13(\mathrm{dd}, 1 \mathrm{H}, J$ $=6.8$ and $1.6 \mathrm{~Hz}), 6.85(\mathrm{~s}, 2 \mathrm{H}), 5.71(\mathrm{~s}, 2 \mathrm{H}), 4.00(\mathrm{~s}, 3 \mathrm{H}), 2.24(\mathrm{~s}$, $3 \mathrm{H}), 1.85$ (s, $6 \mathrm{H}) .{ }^{13} \mathrm{C}\left\{{ }^{1} \mathrm{H}\right\}$ NMR (100 MHz, $\left.\mathrm{CDCl}_{3}\right): \delta 159.9$, 152.0, 137.7, 137.5, 137.1, 136.6, 135.1, 128.1, 124.9, 123.1, 122.1, 121.7, 54.0, 36.7, 21.0, 20.2. Anal. Calcd for $\mathrm{C}_{19} \mathrm{H}_{22} \mathrm{~N}_{3} \mathrm{Br}$ : C, 61.30; H, 5.96; N, 11.29. Found: C, 61.11; H, 6.08; N, 11.44.

Silver Complex 2a. A solution of 1a (397 mg, $1.07 \mathrm{mmol})$, silver oxide (124 mg, $0.54 \mathrm{mmol})$, and sodium iodide $(160.4 \mathrm{mg}, 1.07$ mmol) in $\mathrm{CH}_{2} \mathrm{Cl}_{2}(20 \mathrm{~mL})$ was stirred at room temperature for $24 \mathrm{~h}$. Filtration of the reaction mixture through Celite gave a colorless solution, which was then concentrated. Upon the addition of hexane to the crude reaction mixture, complex 2a was precipi-

(11) (a) Wang, C. Y.; Liu, Y. H.; Peng, S. M.; Liu, S. T. J. Organomet. Chem. 2006, 691, 4012. (b) Garrison, J. C.; Youngs, W. J. Chem. Rev. 2005, 105, 3978. tated and isolated as a white solid (545 mg, 97\%). ${ }^{1} \mathrm{H}$ NMR (400 $\mathrm{MHz} \mathrm{CDCl}_{3}$ ): $\delta 7.69(\mathrm{dd}, 1 \mathrm{H}, J=7.6$ and $7.6 \mathrm{~Hz}, P y), 7.54(\mathrm{~d}$, $1 \mathrm{H}, J=7.6 \mathrm{~Hz}, P y), 7.12(\mathrm{~d}, 1 \mathrm{H}, J=7.6 \mathrm{~Hz}, P y), 7.10(\mathrm{~m}, 1 \mathrm{H}$, Im), 6.89 (s, 2H, Mes), $6.86(\mathrm{~d}, 1 \mathrm{H}, J=1.2 \mathrm{~Hz}, \operatorname{Im}), 5.52(\mathrm{~s}, 2 \mathrm{H})$, 3.87 (s, 3H), 2.29 (s, 3H), $1.94(\mathrm{~s}, 6 \mathrm{H}) .{ }^{13} \mathrm{C}\left\{{ }^{1} \mathrm{H}\right\} \mathrm{NMR}(100 \mathrm{MHz}$, $\left.\mathrm{CDCl}_{3}\right): \delta 184.7(\mathrm{Ag}-\mathrm{C}), 159.5,155.5,137.5,137.1,135.4,128.2$, 124.0, 121.9, 121.4, 121.0, 57.0, 39.1, 21.2, 20.4. Anal. Calcd for $\mathrm{C}_{38} \mathrm{H}_{42} \mathrm{Ag}_{2} \mathrm{I}_{2} \mathrm{~N}_{6}: \mathrm{C}, 43.37 ; \mathrm{H}, 4.02 ; \mathrm{N}, 7.99$. Found: C, 43.37; H, 4.09; N, 7.97.

[(C-pyN $\left.\left.{ }^{\wedge} \mathbf{C}-\mathbf{M e}\right) \operatorname{Ir}(\mathbf{C O D}) \mathbf{C l}\right]$ (3a). A mixture of silver complex 2a $(200 \mathrm{mg}, 0.19 \mathrm{mmol})$ and $[\mathrm{IrCl}(\mathrm{COD})]_{2}(127 \mathrm{mg}, 0.19 \mathrm{mmol})$ in dichloromethane $(25 \mathrm{~mL})$ was stirred at room temperature for $3 \mathrm{~h}$. The resulting solution was filtered through Celite, followed by concentration and crystallization from $\mathrm{CH}_{2} \mathrm{Cl}_{2} /$ hexane to afford a yellow solid of the desired iridium complex $(230 \mathrm{mg}, 97 \%) .{ }^{1} \mathrm{H}$ NMR $\left(400 \mathrm{MHz}, \mathrm{CDCl}_{3}\right): \delta 7.71(\mathrm{dd}, 1 \mathrm{H}, J=7.6$ and $7.6 \mathrm{~Hz}$, $P y), 7.51(\mathrm{~d}, 1 \mathrm{H}, J=7.6 \mathrm{~Hz}, P y), 7.12(\mathrm{~d}, 1 \mathrm{H}, J=7.6 \mathrm{~Hz}, P y)$, $6.92(\mathrm{~s}, 2 \mathrm{H}$, Mes ), $6.88(\mathrm{~s}, 1 \mathrm{H}, I m), 6.78(\mathrm{~s}, 1 \mathrm{H}, I m), 6.13(\mathrm{~d}, 1 \mathrm{H}$, $\left.J=14.8 \mathrm{~Hz}, \mathrm{CH}_{2}\right), 5.48\left(\mathrm{~d}, 1 \mathrm{H}, J=14.8 \mathrm{~Hz}, \mathrm{CH}_{2}\right), 4.63-4.59$ (m, 2H, COD), 3.96 (s, 3H, NMe), 2.98 (br, 1H, COD), 2.87 (br, $1 \mathrm{H}, C O D), 2.31$ (s, 3H, Me), 2.00 (s, 6H, Me), 2.24-1.63 (m, 8H, COD $).{ }^{13} \mathrm{C}\left\{{ }^{1} \mathrm{H}\right\}$ NMR $\left(100 \mathrm{MHz}, \mathrm{CDCl}_{3}\right): \delta 179.8(\mathrm{Ir}-\mathrm{C}), 158.7$, 155.4, 137.1, 137.0, 135.1, 128.0, 123.6, 121.8, 120.8, 120.0, 85.0 (COD), 84.5 (COD), $56.0\left(\mathrm{CH}_{2}\right), 52.1$ (COD), 51.8 (COD), 37.7 (NMe), 34.2 (COD), 33.4 (COD), 30.2 (COD), 29.5 (COD), 21.5, 20.6. Anal. Calcd for $\mathrm{C}_{27} \mathrm{H}_{33} \mathrm{ClIrN}_{3}$ : C, 51.70; H, 5.30; N, 6.70. Found: C, 51.37; H, 4.98; N, 6.45.

[(C-pyN $\mathbf{N}^{\wedge} \mathbf{C}$-Mes $\left.) \operatorname{Ir}(\mathbf{C O D}) \mathbf{C l}\right](\mathbf{3 b})$. The procedure for the preparation of $\mathbf{3 b}$ is similar to that for $\mathbf{3 a}$. Yield: yellow solid (73\%). ${ }^{1} \mathrm{H}$ NMR (400 MHz, $\mathrm{CDCl}_{3}$ ): $\delta 7.77(\mathrm{dd}, 1 \mathrm{H}, J=7.2$ and $7.2 \mathrm{~Hz}$, $P y), 7.63(\mathrm{~d}, 1 \mathrm{H}, J=7.2 \mathrm{~Hz}, P y), 7.18(\mathrm{~d}, 1 \mathrm{H}, J=1.6 \mathrm{~Hz}, I m)$, $7.16(\mathrm{~d}, 1 \mathrm{H}, J=7.2 \mathrm{~Hz}, P y), 7.01$ (s, 1H, Mes), 6.92 (s, 2H, Mes), $6.87(\mathrm{~s}, 1 \mathrm{H}, M e s), 6.70(\mathrm{~d}, 1 \mathrm{H}, J=1.6 \mathrm{~Hz}, I m), 6.21(\mathrm{~d}, 1 \mathrm{H}, J=$ $\left.15.2 \mathrm{~Hz}, \mathrm{CH}_{2}\right), 5.71\left(\mathrm{~d}, 1 \mathrm{H}, J=15.2 \mathrm{~Hz}, \mathrm{CH}_{2}\right), 4.46-4.45(\mathrm{~m}$, $2 \mathrm{H}, C O D), 2.88-2.85(\mathrm{~m}, 1 \mathrm{H}, C O D), 2.67-2.64(\mathrm{~m}, 1 \mathrm{H}, C O D)$, 2.35 (s, 6H, Me), 2.32 (s, 3H, Me), 2.03 (m, 2H, COD), 1.99 (s, $6 \mathrm{H}, M e), 1.95-1.86(\mathrm{~m}, 2 \mathrm{H}, C O D), 1.82$ (s, 3H, Me), 1.79-1.75 $(\mathrm{m}, 2 \mathrm{H}, C O D), 1.53-1.29(\mathrm{~m}, 4 \mathrm{H}, C O D) .{ }^{13} \mathrm{C}\left\{{ }^{1} \mathrm{H}\right\}$ NMR $(100$ $\left.\mathrm{MHz}, \mathrm{CDCl}_{3}\right): \delta 179.6(\mathrm{Ir}-C), 159.1,155.7,138.1,137.1,137.0$, 136.6, 136.4, 135.5, 135.1, 133.9, 129.0, 128.0, 127.7, 123.5, 122.4, 121.3, 120.9, 83.4, 83.2, $56.4\left(\mathrm{CH}_{2}\right), 52.3,51.3,34.6,32.8,29.8$, 29.1, 21.5, 21.4, 20.6, 20.0, 18.1. HR-FAB for $[\mathrm{M}-\mathrm{Cl}]^{+}$: calcd, 696.2930 $\left(\mathrm{C}_{35} \mathrm{H}_{41} \mathrm{~N}_{3}{ }^{193} \mathrm{Ir}\right)$; found, 696.2936. Anal. Calcd for $\mathrm{C}_{35} \mathrm{H}_{41}$ $\mathrm{ClIrN}_{3}$ : C, 57.48; H, 5.65; N, 5.75. Found: C, 57.03; H, 5.33; N, 5.45 .

$\left[\left(C, N-\mathbf{p y N}^{\wedge} \mathbf{C}-\mathrm{Me}\right) \operatorname{Ir}(\mathrm{COD})\right]\left(\mathrm{BF}_{4}\right)(\mathbf{4 a})$. A mixture of 3a (100 $\mathrm{mg}, 0.159 \mathrm{mmol})$ and silver tetrafluoroborate $(32 \mathrm{mg}, 0.16 \mathrm{mmol})$ in $\mathrm{CH}_{2} \mathrm{Cl}_{2}(25 \mathrm{~mL})$ was stirred under nitrogen at the ambient temperature for $1 \mathrm{~h}$. The mixture was filtered through Celite, and the filtrate was added dropwise to a hexane solution. The desired product was precipitated as a brown-red solid (96 mg, 89\%). ${ }^{1} \mathrm{H}$ NMR $\left(400 \mathrm{MHz}, \mathrm{CDCl}_{3}\right): \delta 8.08(\mathrm{dd}, 1 \mathrm{H}, J=7.6$ and $0.8 \mathrm{~Hz}$, $P y), 7.93(\mathrm{dd}, 1 \mathrm{H}, J=7.6$ and $7.6 \mathrm{~Hz}, P y), 7.59(\mathrm{~d}, 1 \mathrm{H}, J=1.6$ $\mathrm{Hz}, I m), 7.31$ (dd, $1 \mathrm{H}, J=7.6$ and $0.8 \mathrm{~Hz}, P y), 7.03$ (s, 1H, Mes), $6.91(\mathrm{~s}, 1 \mathrm{H}, M e s), 6.89(\mathrm{~d}, 1 \mathrm{H}, J=1.6 \mathrm{~Hz}, I m), 5.90(\mathrm{~d}, 1 \mathrm{H}, J=$ $\left.14.8 \mathrm{~Hz}, \mathrm{CH}_{2}\right), 5.85\left(\mathrm{~d}, 1 \mathrm{H}, J=14.8 \mathrm{~Hz}, \mathrm{CH}_{2}\right), 4.19-4.15(\mathrm{~m}$, $1 \mathrm{H}, \mathrm{COD}), 3.79$ (s, 3H, NMe), 3.76-3.73 (m, 1H, COD), 3.47$3.43(\mathrm{~m}, 1 \mathrm{H}, C O D), 2.92-2.86(\mathrm{~m}, 1 \mathrm{H}, C O D), 2.36$ (s, 3H, Me), 2.2-2.17 (m, 2H, COD), 2.07 (s, 3H, Me), 1.85-1.79 (m, 5H, Me and $C O D), 1.51-1.42(\mathrm{~m}, 1 \mathrm{H}, C O D), 1.23-1.08(\mathrm{~m}, 3 \mathrm{H}, C O D)$. ${ }^{13} \mathrm{C}\left\{{ }^{1} \mathrm{H}\right\}$ NMR $\left(100 \mathrm{MHz}, \mathrm{CDCl}_{3}\right): \delta 173.0(\mathrm{Ir}-C), 160.9,153.7$, 139.4, 139.0, 137.5, 135.5, 134.7, 128.5, 128.1, 128.0, 124.7, 122.2, 122.0, 86.3 (COD), 84.0 (COD), $60.9(C O D), 55.2\left(\mathrm{CH}_{2}\right), 54.0$ 
Table 1. Crystal Data and Structure Refinement for Complexes $\mathbf{2 a}, \mathbf{3 b}$, and $\mathbf{5 b}$

$\begin{array}{llll}\text { complex } & \mathbf{2 a} & \mathbf{3 b} & \mathbf{5 b} \\ \text { formula } & \mathrm{C}_{19} \mathrm{H}_{21} \mathrm{AgIN}_{3} & \mathrm{C}_{35} \mathrm{H}_{41} \mathrm{ClIrN}_{3} & \mathrm{C}_{29} \mathrm{H}_{29} \mathrm{BF}_{4} \mathrm{IrN}_{3} \mathrm{O}_{2} \cdot \mathrm{CHCl}_{3} \\ \text { fw } & 526.16 & 731.36 & 849.93 \\ T, \mathrm{~K} & 295(2) & 295(2) & 295(2) \\ \text { cryst syst } & \text { triclinic } & \text { monoclinic } & P \overline{1} \\ \text { space group } & P \overline{1} & P 2 \mathrm{H}_{1} / c & 7.7440(1) \\ a, \AA & 7.0698(1) & 9.8802(1) & 20.6300(2) \\ b, \AA & 8.3572(2) & 12.2907(1) & 21.1440(2) \\ c, \AA & 17.2918(4) & 26.4927(3) & 89.8300(8) \\ \alpha, \text { deg } & 91.228(1) & 90 & 86.0530(8) \\ \beta, \text { deg } & 91.613(1) & 93.446(1) & 87.2310(8) \\ \gamma, \text { deg } & 107.051(1) & 90 & 3365.99(6) ; 4 \\ V, \AA \text { A } & 975.90(4) ; 2 & 3211.31(6) ; 4 & 1.677 \\ d(\text { calcd), Mg/m } & 1.791 & 1.513 & 1664 \\ F(0,0,0) & 512 & 1464 & 0.25 \times 0.20 \times 0.15 \\ \text { crystal size, mm } & 0.20 \times 0.15 \times 0.10 & 0.20 \times 0.18 \times 0.15 & 21420 \\ \text { rflcns collected } & 7316 & 20471 & 11820\left(R_{\text {int }}=0.0382\right) \\ \text { indep rflcns } & 4402\left(R_{\text {int }}=0.0308\right) & 7340\left(R_{\text {int }}=0.0416\right) & 2.17-25.00 \\ \theta \text { range, deg } & 1.18-27.49 & 1.83-27.49 & 1.180 \\ \text { refined method } & & \text { full-matrix least squares on } F^{2} & \\ \text { GOF on } F^{2} & 0.974 & 1.162 & \mathrm{R} 1=0.0728, \mathrm{wR} 2=0.2076 \\ R \text { indices }[I>2 \sigma(I)] & \mathrm{R} 1=0.0356, \text { wR2 }=0.1137 & \mathrm{R} 1=0.0352, \text { wR2 }=0.0894 & \end{array}$

(COD), 37.2 (NMe), 35.6 (COD), 31.6 (COD), 30.1 (COD), 27.6 (COD), $21.6(\mathrm{Me}), 21.5(\mathrm{Me}), 21.4(\mathrm{Me})$. Anal. Calcd for $\mathrm{C}_{27} \mathrm{H}_{33^{-}}$ $\mathrm{BF}_{4} \mathrm{IrN}_{3}$ : C, 47.79; H, 4.90; N, 6.19. Found: C, 47.43; H, 4.54; $\mathrm{N}, 5.97$.

$\left[\left(C, N-p y N^{\wedge} \mathbf{C}\right.\right.$-Mes $\left.) \operatorname{Ir}(\mathbf{C O D})\right]\left(\mathbf{B F}_{4}\right)(\mathbf{4 b})$. The procedure for the preparation of $\mathbf{4 b}$ is similar to that for $\mathbf{4 a}$. Yield: brown-red solid (105 mg, 86\%). ${ }^{1} \mathrm{H}$ NMR (400 MHz, $\left.\mathrm{CDCl}_{3}\right): \delta 8.19(\mathrm{~d}, 1 \mathrm{H}, J=$ $8.0 \mathrm{~Hz}, P y), 7.96(\mathrm{dd}, 1 \mathrm{H}, J=8.0$ and $7.6 \mathrm{~Hz}, P y), 7.89(\mathrm{~s}, 1 \mathrm{H}$, Im), $7.30(\mathrm{~d}, 1 \mathrm{H}, J=7.6 \mathrm{~Hz}, P y), 6.96$ (s, 1H, Mes), 6.92 (s, 2H, Im + Mes), $6.84(\mathrm{~s}, 1 \mathrm{H}$, Mes $), 6.68(\mathrm{~s}, 1 \mathrm{H}$, Mes $), 6.07(\mathrm{~d}, 1 \mathrm{H}, J=$ $\left.14.4 \mathrm{~Hz}, \mathrm{CH}_{2}\right), 5.97$ (d, $\left.1 \mathrm{H}, J=14.4 \mathrm{~Hz}, \mathrm{CH}_{2}\right), 4.46-4.43$ (m, $1 \mathrm{H}, C O D), 3.50-3.42(\mathrm{~m}, 2 \mathrm{H}, C O D), 2.54-2.46(\mathrm{~m}, 1 \mathrm{H}, C O D)$, 2.35 (s, 3H, Me), 2.30 (s, 3H, Me), 2.19 (s, 3H, Me), 2.15-2.10 (m, 2H, COD), 1.99-1.65 (m, 6H, COD), 1.97 (s, 3H, Me), 1.91 (s, 3H, Me), 1.63 (s, 3H, Me). ${ }^{13} \mathrm{C}\left\{{ }^{1} \mathrm{H}\right\}$ NMR (100 MHz, $\left.\mathrm{CDCl}_{3}\right)$ : $\delta 171.3(\mathrm{Ir}-\mathrm{C}), 161.5,153.8,139.4,139.1,139.0,137.5,136.3$, $135.1,135.0,134.8,134.3,128.8,128.6,128.5,127.8,127.7,86.2$, 80.3, 60.0, 58.3, $55.7\left(\mathrm{CH}_{2}\right), 36.8,33.6,28.8,26.5,24.1,21.5,21.4$, 21.3, 18.7, 18.4. Anal. Calcd for $\mathrm{C}_{35} \mathrm{H}_{41} \mathrm{BF}_{4} \mathrm{IrN}_{3}$ : C, 53.71; H, 5.28; N, 5.37. Found: C, 53.21; H, 5.01; N, 5.05.

$\left[\left(\boldsymbol{C}, \boldsymbol{N}\right.\right.$-pyN $\left.\left.\mathbf{N}^{\wedge} \mathbf{C}-\mathrm{Me}\right) \operatorname{Ir}(\mathbf{C O})_{2}\right]\left(\mathbf{B F}_{4}\right) \quad(\mathbf{5 a})$. Carbon monoxide gas was passed through a solution of $\mathbf{4 a}(10 \mathrm{mg}, 0.015 \mathrm{mmol})$ in dichloromethane $(25 \mathrm{~mL})$ with stirring for $3 \mathrm{~h}$. The solution slowly turned yellow. The reaction mixture was filtered through Celite, and the filtrate was concentrated. Recrystallization of the residue from a solution of chloroform and hexane gave 5a as a yellow crystalline solid (9 mg, 95\%). ${ }^{1} \mathrm{H}$ NMR (400 MHz, $\left.\mathrm{CDCl}_{3}\right): \delta 8.23$ $(\mathrm{d}, 1 \mathrm{H}, J=7.6 \mathrm{~Hz}, P y), 8.14(\mathrm{dd}, 1 \mathrm{H}, J=7.6$ and $7.6 \mathrm{~Hz}, P y)$, 7.79 (s, 1H, Im) 7.47 (d, 1H, J = 7.6 Hz,Py), $7.18(\mathrm{~s}, 1 \mathrm{H}, I m)$, 7.02 (s, 1H, Mes), 7.00 (s, 1H, Mes), 5.96 (d, 1H, J = $14.0 \mathrm{~Hz}$, $\mathrm{CH}_{2}$ ), 5.44 (d, $1 \mathrm{H}, J=14.0 \mathrm{~Hz}, \mathrm{CH}_{2}$ ), 3.86 (s, 3H, NMe), 2.39 (s, $3 \mathrm{H}, M e), 2.10$ (s, 3H, Me), 1.74 (s, 3H, Me). ${ }^{13} \mathrm{C}\left\{{ }^{1} \mathrm{H}\right\} \mathrm{NMR}(100$ $\mathrm{MHz}, \mathrm{CDCl} 3): \delta 179.2(\mathrm{CO}), 170.3(\mathrm{CO}), 169.7(\mathrm{Ir}-C), 163.3$, 154.1, 141.5, 140.3, 138.0, 135.3, 134.5, 128.9, 128.8, 127.8, 125.6, 123.5, 123.0, $54.5\left(\mathrm{CH}_{2}\right), 37.7(\mathrm{NMe}), 21.7,21.4,21.3 . \mathrm{IR}(\mathrm{KBr}$, $\left.\mathrm{cm}^{-1}\right): \quad v(\mathrm{CO}) 2064$ (s), 2004 (s). Anal. Calcd for $\mathrm{C}_{21} \mathrm{H}_{21} \mathrm{BF}_{4}$ $\mathrm{IrN}_{3} \mathrm{O}_{2}$ : C, 40.26; H, 3.38; N, 6.71. Found: C, 40.01; H, 3.00; N, 6.35 .

$\left[\left(C, N\right.\right.$-py $\left.\left.\mathbf{N}^{\wedge} \mathbf{C}-\mathrm{Mes}\right) \operatorname{Ir}(\mathbf{C O})_{2}\right]\left(\mathbf{B F}_{4}\right)(\mathbf{5 b})$. The procedure for the preparation of $\mathbf{5 b}$ is similar to that for $\mathbf{5 a}$. Yield: yellow crystalline solid (40.1 mg, 94\%). ${ }^{1} \mathrm{H}$ NMR (400 MHz, $\left.\mathrm{CDCl}_{3}\right): \delta 8.36(\mathrm{~d}$, $1 \mathrm{H}, J=7.2 \mathrm{~Hz}, P y), 8.17(\mathrm{dd}, 1 \mathrm{H}, J=8.0$ and $7.2 \mathrm{~Hz}, P y), 8.08$ (s, 1H, Im), 7.47 (d, 1H, J = 8.0 Hz, Py), 6.97 (s, 2H, Mes), 6.95

(s, 1H, Im), 6.94 (s, 2H, Mes), 6.00-5.60 (br, 2H, $\left.\mathrm{CH}_{2}\right), 2.34(\mathrm{~s}$, $6 \mathrm{H}, M e), 1.97(\mathrm{~s}, 6 \mathrm{H}, \mathrm{Me}), 1.93(\mathrm{~s}, 6 \mathrm{H}, M e) .{ }^{13} \mathrm{C}\left\{{ }^{1} \mathrm{H}\right\} \mathrm{NMR}(100$ $\mathrm{MHz}, \mathrm{CDCl}_{3}$ ): $\delta 172.0(\mathrm{CO}), 171.3(\mathrm{CO}), 167.3(\mathrm{Ir}-C), 164.1$, 153.9, 141.8, 140.1, 140.0, 135.8, 133.4, 129.0, 128.5, 128.3, 126.0, 124.0, 123.5, $54.7\left(\mathrm{CH}_{2}\right), 21.6,21.5,18.4 . \mathrm{IR}\left(\mathrm{KBr}, \mathrm{cm}^{-1}\right): v-$ (CO) 2071 (s), 2004 (s). Anal. Calcd for $\mathrm{C}_{29} \mathrm{H}_{29} \mathrm{BF}_{4} \mathrm{IrN}_{3} \mathrm{O}_{2}$ : C, 47.68; H, 4.00; N, 5.75. Found: C, 47.32; H, 3.73; N, 5.55.

General Procedures for the Reduction of Benzophenone. A mixture of benzophenone $(2.5 \mathrm{mmol})$, the iridium complex $(2.5 \times$ $\left.10^{-3} \mathrm{mmol}\right)$, and $\mathrm{KOH}(0.1 \mathrm{M})$ in isopropyl alcohol $(2 \mathrm{~mL})$ was heated under refluxing temperature for $12 \mathrm{~h}$. Upon cooling, the solvent was removed under reduced pressure and the residue was dissolved in $1 \mathrm{~mL}$ of $\mathrm{CH}_{2} \mathrm{Cl}_{2}$ for gas chromatography (GC) analysis. Product analysis was also performed by a ${ }^{1} \mathrm{H}$ NMR spectroscopic method. The results are summarized in Table 4.

General Procedures for the Reduction of Nitroarenes. Catalytic reactions were typically performed with $1 \mathrm{mmol}$ of substrate, the iridium complex, and $\mathrm{KOH}$ in isopropyl alcohol $(4 \mathrm{~mL})$ under nitrogen. The progress of the reaction was monitored by ${ }^{1} \mathrm{H}$ NMR at regular intervals. The reaction mixture was passed through Celite to remove the metal species and salts. The filtrate was concentrated and identified by GC and ${ }^{1} \mathrm{H}$ NMR. In the case of the azo products, the reaction mixture was chromatographed on silica gel with elution of dichloromethane/ethyl acetate and the colored fraction was collected. The desired product was obtained upon concentration and characterized by ${ }^{1} \mathrm{H}$ NMR spectroscopy. Spectral data of all known compounds are consistent with those reported in the literature. Spectral data of the products are provided in the Supporting Information. All results are summarized in Tables 5 and 6.

Crystallography. Crystals suitable for X-ray determination were obtained for $\mathbf{2 a}, \mathbf{3 b}$, and $\mathbf{5 b}$ by recrystallization at room temperature. Cell parameters were determined by a Siemens SMART CCD diffractometer. Crystal data of these complexes are listed in Table 1. All ORTEP plots are drawn with $30 \%$ probability ellipsoids and partial labeling for clarity in Figures $1-3$. Other crystallographic data are presented as Supporting Information.

\section{Results and Discussion}

Preparation of Iridium Complexes. The method for the preparation of iridium carbene complexes is similar to that 
Wang et al.

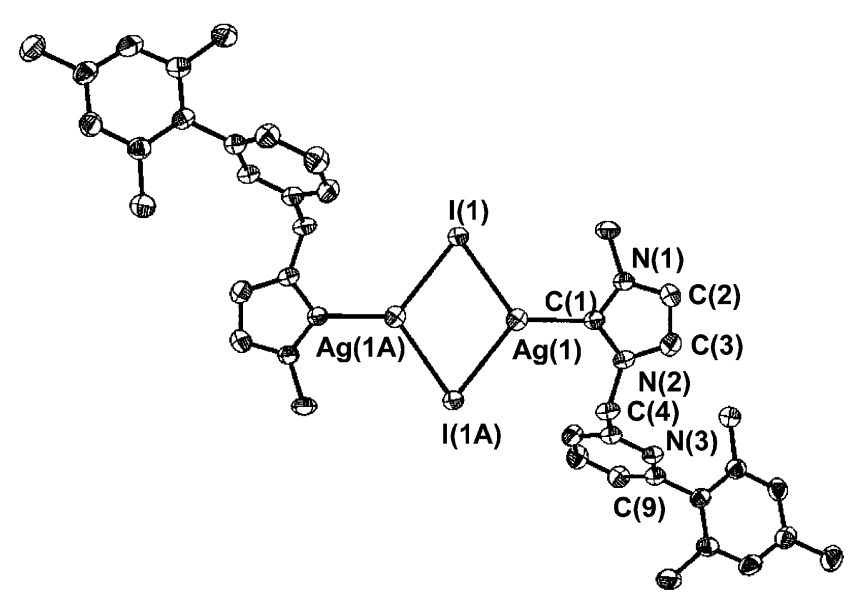

Figure 1. ORTEP plot of complex 2a (drawn with $30 \%$ probability ellipsoids): $\mathrm{Ag}-\mathrm{C} 2.150(3) \AA ⿻$, C(1) $-\mathrm{N}(1)$ 1.337(4) $\AA, \mathrm{C}(1)-\mathrm{N}(2) 1.364-$ (5) $\AA, \mathrm{C}(1)-\mathrm{Ag}(1)-\mathrm{I}(1) 125.68(9)^{\circ}, \mathrm{Ag}(1)-\mathrm{I}(1)-\mathrm{Ag}(1 \mathrm{~A}) 74.62(1)^{\circ}$.

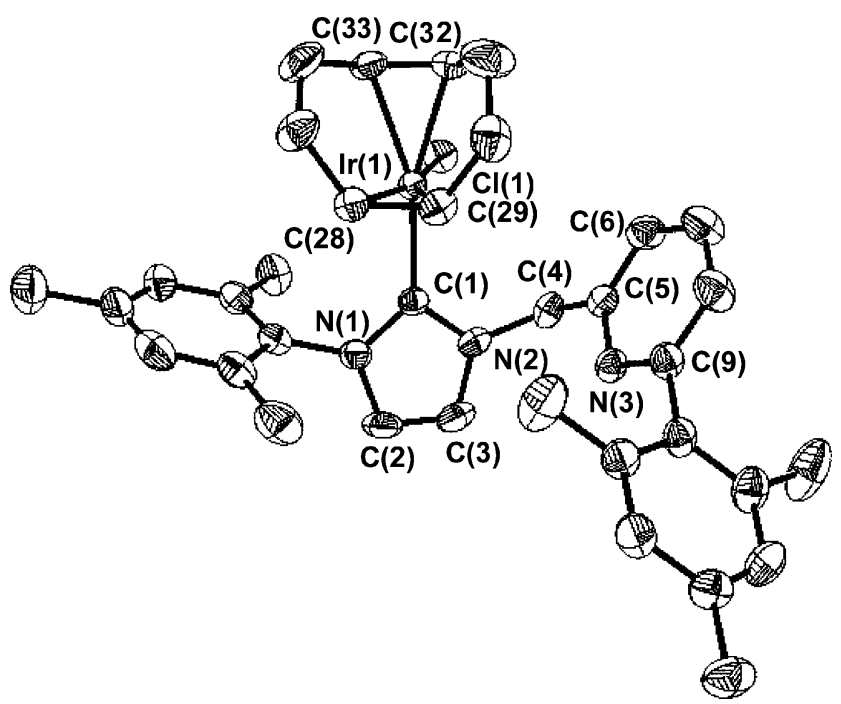

Figure 2. Molecular structure of $\mathbf{3 b}$ (drawn with $30 \%$ probability ellipsoids).

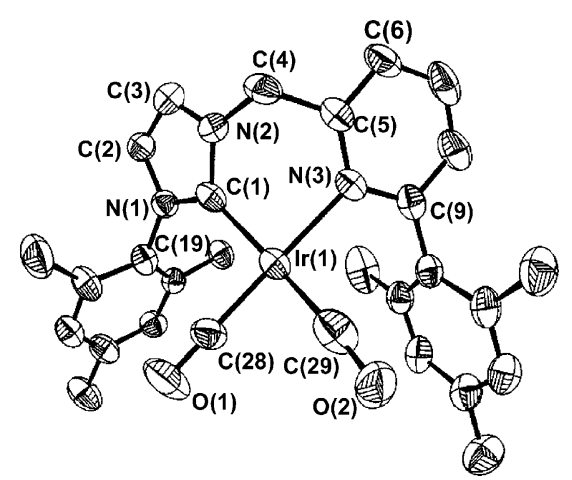

Figure 3. ORTEP plot of the cationic portion of complex $\mathbf{5 b}$ (drawn with $30 \%$ probability ellipsoids).

of the rhodium complexes prepared in our laboratory. ${ }^{11 a}$ In brief, the pyridinylimidazolium salt $\mathbf{1}$, the precursor for the carbene ligand, was prepared by a simple substitution reaction of 2-(bromomethyl)-6-mesitylpyridine with the corresponding imidazole. Deprotonation of the imidazolium salt 1 with a strong base, which was expected to produce the corresponding free carbene, unfortunately failed presum-
Scheme $1^{a}$

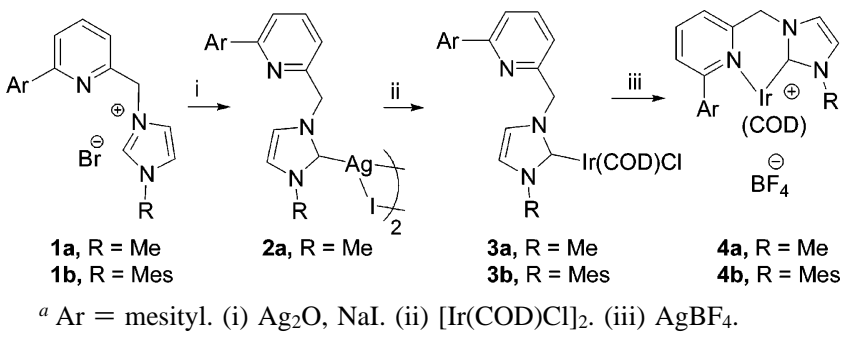

ably because of interference from the deprotonation of benzylic methylene protons. ${ }^{12}$ Alternatively, the imidazolium salt 1 was converted into its silver carbene complex (Scheme 1) via the reaction of $\mathbf{1}$ with excess of $\mathrm{Ag}_{2} \mathrm{O}$ in a dichloromethane solution. ${ }^{13}$ The ${ }^{13} \mathrm{C}\left\{{ }^{1} \mathrm{H}\right\}$ NMR spectrum of the silver complex 2a shows a characteristic shift for $\mathrm{Ag}-$ $\mathrm{C}$ (carbene) at $\delta 184.7$, which is reasonably assigned to the $2 C$-imidazol-2-ylidene(carbene) carbon, whereas $\mathrm{Ag}-\mathrm{C}$ (carbene) for complex $\mathbf{2 b}$ appears at $\delta 183.5$ and is in a similar range as that for $\mathrm{Ag}-\mathrm{C}$ (carbene). ${ }^{13}$ These spectral data clearly illustrate the formation of a silver carbene complex.

Further structural confirmation is given by X-ray analyses. The ORTEP plot of 2a is shown in Figure 1, while the crystal structure of $\mathbf{2 b}$ has been reported previously. ${ }^{11 a}$ Unlike $\mathbf{2 b}$, the molecule comprises two silver atoms bridged by iodide

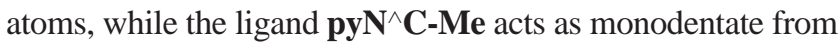
the carbene end. The four-membered ring defined by Ag(1) $-\mathrm{I}(1)-\mathrm{Ag}(1 \mathrm{~A})-\mathrm{I}(1 \mathrm{~A})$ is in a planar arrangement. The long distance of $\mathrm{Ag}-\mathrm{Ag}(3.40 \AA)$ indicates no metal-metal interaction. ${ }^{11 \mathrm{~b}} \mathrm{The} \mathrm{Ag}-\mathrm{C}$ bond length is $2.150(3) \AA$, similar to that of complex $\mathbf{2 b}$ [2.108(4) $\AA]$.

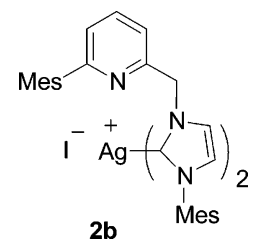

Treatment of $[\operatorname{Ir}(\mathrm{COD}) \mathrm{Cl}]_{2}$ with the silver carbene complexes $\mathbf{2}$ in dichloromethane at ambient temperature gave the desired iridium complexes $\mathbf{3}$ as yellow solids in excellent yields. Characterization of these complexes, $\mathbf{3 a}$ and $\mathbf{3} \mathbf{b}$, was performed by both spectroscopic and elemental analyses. ${ }^{13} \mathrm{C}$ $\left\{{ }^{1} \mathrm{H}\right\}$ NMR data for the coordinating carbene carbons appear at $\delta 179.8$ for $\mathbf{3 a}$ and $\delta 179.6$ for $\mathbf{3 b}$, suggesting the formation of the $\mathrm{Ir}-\mathrm{C}$ bond. These signals are all in the typical range for $\mathrm{Ir}-\mathrm{C}$ (carbene) observed for the analogues. ${ }^{14}$ The ${ }^{1} \mathrm{H}$ NMR shifts corresponding to the proton of the pyrindinyl ring are essentially similar to those of the silver complexes (Table 2), indicating that the pyridinyl nitrogen donor remains uncoordinated. Furthermore, ${ }^{1} \mathrm{H}$ NMR spectra

(12) McGuinness, D. S.; Cavell, K. J. Organometallics 2000, 19, 741.

(13) Wang, H. M. J.; Lin, I. J. B. Organometallics 1998, 17, 972.

(14) Chianese, A. R.; Li, X.; Janzen, M. C.; Faller, J. W.; Crabtree, R. H. Organometallics 2003, 22, 1663. 
Table 2. ${ }^{1} \mathrm{H}$ NMR Spectral Data for Pyridinyl Hydrogen Atoms in Silver and Iridium Complexes

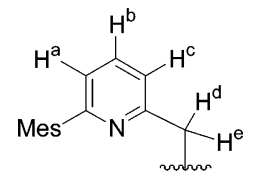

\begin{tabular}{ccccc}
\hline complex & \multicolumn{1}{c}{$\mathrm{H}^{\mathrm{a}}$} & $\mathrm{H}^{\mathrm{b}}$ & $\mathrm{H}^{\mathrm{c}}$ & $\mathrm{H}^{\mathrm{d}} ; \mathrm{H}^{\mathrm{e}}$ \\
\hline $\mathbf{2 a}$ & $7.54(\mathrm{~d}, J=7.6 \mathrm{~Hz})$ & $7.69(\mathrm{dd}, J=7.6$ and $7.6 \mathrm{~Hz})$ & $7.12(\mathrm{~d}, J=7.6 \mathrm{~Hz})$ & \\
$\mathbf{2} \mathbf{b}^{a}$ & $7.45(\mathrm{~d}, J=8.0 \mathrm{~Hz})$ & $7.74(\mathrm{dd}, J=8.0$ and $8.0 \mathrm{~Hz})$ & $7.16(\mathrm{~d}, J=8.0 \mathrm{~Hz})$ & \\
$\mathbf{3 a}$ & $7.51(\mathrm{~d}, J=7.6 \mathrm{~Hz})$ & $7.71(\mathrm{dd}, J=7.6$ and $7.6 \mathrm{~Hz})$ & $7.12(\mathrm{~d}, J=7.6 \mathrm{~Hz})$ & $6.13(\mathrm{~d}, J=14.8 \mathrm{~Hz}) ;$ \\
& & & $5.48(\mathrm{~d}, J=14.8 \mathrm{~Hz})$ \\
$\mathbf{3 b}$ & $7.63(\mathrm{~d}, J=7.2 \mathrm{~Hz})$ & $7.77(\mathrm{dd}, J=7.2$ and $7.2 \mathrm{~Hz})$ & $7.16(\mathrm{~d}, J=7.2 \mathrm{~Hz})$ & $6.21(\mathrm{~d}, J=15.2 \mathrm{~Hz}) ;$ \\
& & & $5.71(\mathrm{~d}, J=15.2 \mathrm{~Hz})$ \\
$\mathbf{4 a}$ & $7.93(\mathrm{dd}, J=7.6$ and $0.8 \mathrm{~Hz})$ & $8.08(\mathrm{dd}, J=7.6$ and $7.6 \mathrm{~Hz})$ & $7.31(\mathrm{dd}, J=7.6 \mathrm{and} 0.8 \mathrm{~Hz})$ & $5.90(\mathrm{~d}, J=14.8 \mathrm{~Hz}) ;$ \\
& & & & $5.85(\mathrm{~d}, J=14.8 \mathrm{~Hz})$ \\
$\mathbf{4 b}$ & $8.19(\mathrm{~d}, J=8.0 \mathrm{~Hz})$ & $7.96(\mathrm{dd}, J=8.0$ and $7.6 \mathrm{~Hz})$ & $7.30(\mathrm{~d}, J=7.6 \mathrm{~Hz})$ & $6.07(\mathrm{~d}, J=14.4 \mathrm{~Hz}) ;$ \\
& & & $5.97(\mathrm{~d}, J=14.4 \mathrm{~Hz})$ \\
$\mathbf{5 a}$ & $8.23(\mathrm{~d}, J=7.26 \mathrm{~Hz})$ & $8.14(\mathrm{dd}, J=7.6$ and $7.6 \mathrm{~Hz})$ & $7.47(\mathrm{~d}, J=7.6 \mathrm{~Hz})$ & $5.96(\mathrm{~d}, J=14.0 \mathrm{~Hz}) ;$ \\
& & & & $5.44(\mathrm{~d}, J=14.0 \mathrm{~Hz})$ \\
$\mathbf{5 b}$ & $8.36(\mathrm{~d}, J=7.2 \mathrm{~Hz})$ & $8.17(\mathrm{dd}, J=8.0$ and $7.2 \mathrm{~Hz})$ & $7.47(\mathrm{~d}, J=8.0 \mathrm{~Hz})$ & $6.00-5.60(\mathrm{br}, 2 \mathrm{H})$
\end{tabular}

${ }^{a}$ Reference 11a.

Table 3. Selected Bond Distances and Bond Angles of Iridium Carbene Complexes $\mathbf{3 b}$ and $\mathbf{5 b}$

\begin{tabular}{lcc}
\hline \multicolumn{1}{c}{ complex } & $\mathbf{3 b}, \mathrm{X}=\mathrm{Cl}(1)$ & $\mathbf{5 b}, \mathrm{X}=\mathrm{N}(3)$ \\
\hline $\operatorname{Ir}(1)-\mathrm{C}(1)$ & $2.040(5)$ & $2.05(1)$ \\
$\operatorname{Ir}(1)-\mathrm{C}(28)$ & $2.098(4)$ & $1.81(2)$ \\
$\operatorname{Ir}(1)-\mathrm{C}(29)$ & $2.099(5)$ & $1.87(2)$ \\
$\operatorname{Ir}(1)-\mathrm{C}(32)$ & $2.180(5)$ & \\
$\operatorname{Ir}(1)-\mathrm{C}(33)$ & $2.167(5)$ & \\
$\operatorname{Ir}(1)-\mathrm{X}$ & $2.385(1)$ & $2.14(1)$ \\
& & \\
$\mathrm{N}(1)-\mathrm{C}(1)-\operatorname{Ir}(1)$ & $129.9(3)$ & $136.3(9)$ \\
$\mathrm{N}(2)-\mathrm{C}(1)-\operatorname{Ir}(1)$ & $126.4(3)$ & $120.2(9)$ \\
$\mathrm{C}(1)-\operatorname{Ir}(1)-\mathrm{X}$ & $91.2(1)$ & $86.2(4)$ \\
$\mathrm{C}(1)-\operatorname{Ir}(1)-\mathrm{C}(28)$ & $92.2(2)$ & $93.8(6)$ \\
$\mathrm{C}(1)-\operatorname{Ir}(1)-\mathrm{C}(29)$ & $91.8(2)$ & $84.5(7)$ \\
$\mathrm{C}(28)-\operatorname{Ir}(1)-\mathrm{C}(29)$ & $39.8(2)$ & $84.5(7)$
\end{tabular}

of both 3a and $\mathbf{3 b}$ display an AM type of splitting pattern for the methylene protons $\left(\mathrm{H}^{\mathrm{d}}\right.$ and $\mathrm{H}^{\mathrm{e}}$, respectively). The detailed coordination sphere around the metal center of $\mathbf{3 b}$ is confirmed by the X-ray crystal structural analysis.

The complete molecular structure of $\mathbf{3 b}$ is shown in Figure 2. Selected bond distances and bond angles are listed in Table 3. The structural determination shows that the molecular geometry around the iridium ion is in square-planar arrangement with two coordination sites occupied by carbene and chloride in a cis fashion. The average distance of $\mathrm{Ir}-\mathrm{C}(\mathrm{COD})$ trans to the carbene donor $(2.17 \AA)$ appears to be longer than those in the cis arrangement $(2.10 \AA)$, suggesting that the $\sigma$-donor nature of the diaminocarbene is stronger than that of the chloride. No major deviation was observed in the bond lengths (Table 3). It is noted that the imidazol-2ylidene ring is bisected with the coordination plane by ca. $73.2^{\circ}$.

The chelation of $\mathbf{p y} \mathbf{N}^{\wedge} \mathbf{C}-\mathbf{R}$ toward the iridium center can be achieved by the treatment of $\mathbf{3}$ with an equimolar amount of $\mathrm{AgBF}_{4}$, leading to the ligand substitution of chloride by the pyridinyl nitrogen. The appearance of $\delta 173.30$ for $\mathbf{4 a}$ and $\delta 171.3$ for $\mathbf{4 b}$ in the ${ }^{13} \mathrm{C}\left\{{ }^{1} \mathrm{H}\right\}$ NMR spectra was assigned to the carbene carbon atoms, which are essentially similar to those of $\mathbf{3 a}$ and $\mathbf{3 b}$. All of the ${ }^{1} \mathrm{H}$ NMR signals of the pyridinyl hydrogen atoms in $\mathbf{4 a}$ and $\mathbf{4 b}$ are shifted downfield relative to those in the silver complexes and $\mathbf{3 a}$ and $\mathbf{3} \mathbf{b}$, indicating chelation of the $\mathbf{p y} \mathbf{N}^{\wedge} \mathbf{C}-\mathbf{R}$ ligand. It is noticed that ${ }^{1} \mathrm{H}$ NMR spectra of $\mathbf{4 a}$ and $\mathbf{4 b}$ exhibit an $\mathrm{AB}$ type of splitting pattern for the methylene protons (Table 2). Besides the spectral data, elemental analyses are consistent with the proposed formula.

Under an atmospheric pressure of carbon monoxide, a stirred solution of $\mathbf{4 a}$ and $\mathbf{4 b}$ gave the carbonyl-substituted iridium complexes $\mathbf{5 a}$ and $\mathbf{5 b}$, respectively (eq 1). IR spectra of these complexes show two carbonyl stretching bands at 2064 and $2004 \mathrm{~cm}^{-1}$ for $\mathbf{5 a}$ as well as 2071 and $2004 \mathrm{~cm}^{-1}$ for $\mathbf{5 b}$, characteristic of the iridium dicarbonyl moiety. The coordination of the strong $\pi$-acid ligands around the metal center causes the downfield shift of the pyridinyl protons in the ${ }^{1} \mathrm{H}$ NMR spectrum (Table 2). In addition to the spectral data, an X-ray single-crystal structure of $\mathbf{5 b}$ was determined to confirm the coordination environment of the complex.

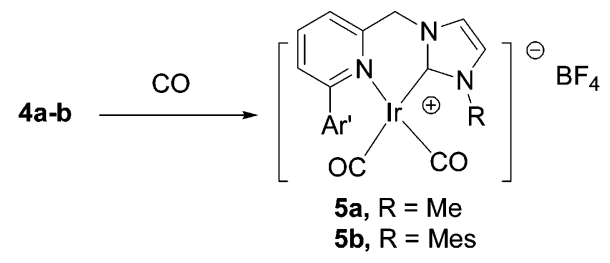

An ORTEP diagram of $\mathbf{5 b}$ is represented in Figure 3, and selected bond distances and bond angles can be found in Table 3. As expected, the geometry around the metal center is square-planar, with the chelating $\mathbf{p y} \mathbf{N}^{\wedge} \mathbf{C}$-Me [bite angle $86.2(4)^{\circ}$ ] and two carbonyl ligands. The chelating ring is adopted into a boat conformation, which allows the two methylene protons to be in different environments, which is in agreement with the spectroscopic observation. The ${ }^{1} \mathrm{H}$ NMR shifts of $-\mathrm{CH}_{2}-$ appear as two sets of doublets at $\delta$ 5.96 and 5.44 with the germinal coupling constant $\sim 14 \mathrm{~Hz}$. All $\mathrm{M}-\mathrm{C}$ bond lengths, including $\mathrm{Ir}-\mathrm{C}$ (carbene) [2.05(1) $\AA]$ and $\mathrm{Ir}-\mathrm{C}$ (carbonyl) [1.81(2) and 1.87(2) $\AA$ ], lie in the 


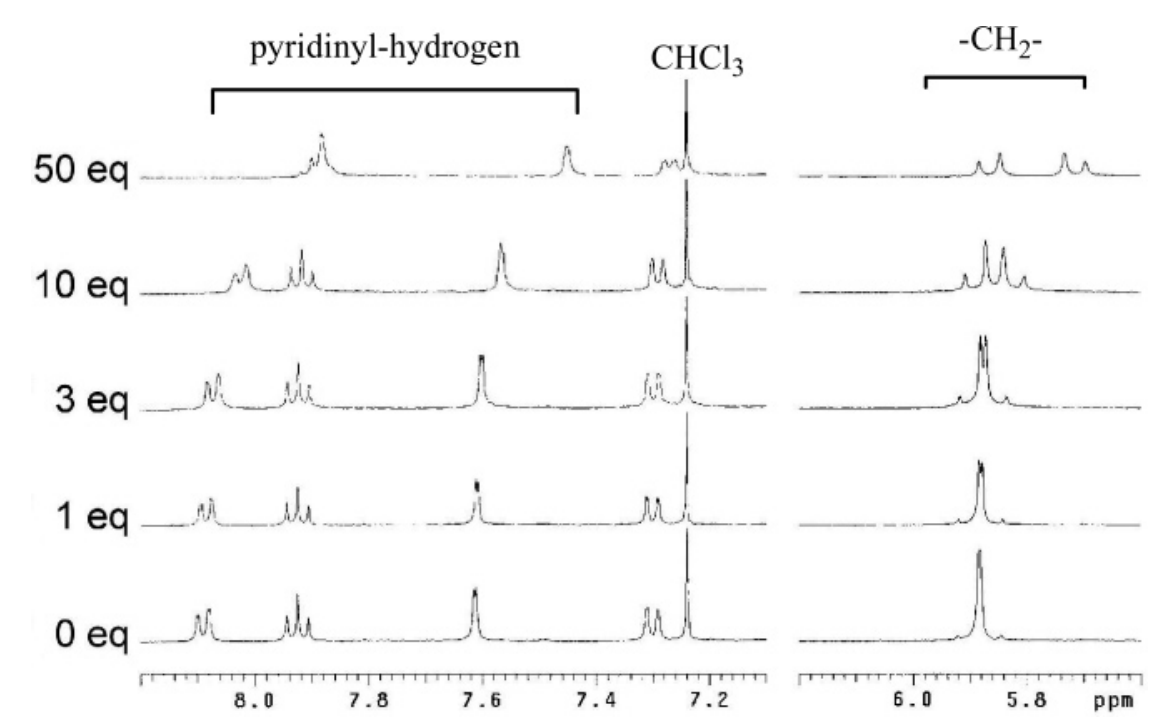

Figure 4. ${ }^{1} \mathrm{H}$ NMR spectra of $\mathbf{4 a}$ in the presence of various amounts of acetonitrile in $\mathrm{CDCl}_{3}$.

normal range, except the angle of $\mathrm{N}(1)-\mathrm{C}(1)-\operatorname{Ir}[136.3-$ $\left.(9)^{\circ}\right]$. The large deviation from $120^{\circ}$ of this angle is presumably caused by the steric interaction of the mesityl group and the carbonyl ligand around the metal center. It is also noticed that the $\mathrm{Ir}-\mathrm{C}$ (carbonyl) trans to the carbene moiety appears to be longer than that of the cis orientaion by about $0.06 \AA$, as anticipated, because of the trans influence.

Ligand Lability. Nitrogen-donor ligands are, in general, more labile than those containing the more strongly binding carbene donors. In solution, the pyridinyl nitrogen donor of 4 undergoes dissociation with added acetonitrile, and NMR experiments were applied to study the exchange. Various amounts of acetonitrile were added to a $\mathrm{CDCl}_{3}$ solution of $4 \mathbf{a}(0.01 \mathrm{M})$, and the ${ }^{1} \mathrm{H}$ NMR spectra of these samples were recorded at ambient temperature (Figure 4). As the concentration of acetonitrile is increased, the signals of the pyridinyl hydrogen atoms and the methylene unit broaden. In addition, the resonances of the pyridinyl hydrogen atoms shift upfield, whereas the splitting patterns corresponding to the methylene unit are changed from the $\mathrm{AB}$ system to the $\mathrm{AM}$ system. For the ${ }^{1} \mathrm{H}$ NMR spectrum of $\mathbf{4 a}$ in the presence of excess of acetonitrile, both the chemical shifts and the splitting pattern resemble those of complex 3a in $\mathrm{CDCl}_{3}$, indicating that the coordinating pyridinyl nitrogen has been replaced by the acetonitrile. Complex $\mathbf{4 b}$ behaves similarly.

Hydrogen-Transfer Reduction. The hydrogen-transfer reduction of a carbonyl function catalyzed by transition-metal complexes is well-documented (Scheme 2). ${ }^{15}$ Likewise, the iridium complexes $\mathbf{3}-\mathbf{5}$, with the mixed carbene-pyridinyl nitrogen donors, are effective for the reduction of benzophenone. A mixture of substrate, the iridium complex $(0.1 \mathrm{~mol}$ $\%)$, and $\mathrm{KOH}(0.1 \mathrm{M})$ in isopropyl alcohol was heated to reflux for $12 \mathrm{~h}$, and the product was obtained by a simple workup procedure. The results of the reduction catalyzed by 3-5 are compiled in Table 4.

(15) Recent review: Saluzzo, C.; Lemaire, M. Adv. Synth. Catal. 2002, 344,915 and references cited therein.
Scheme 2

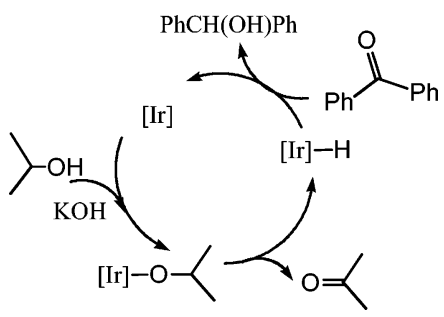

Table 4. Catalytic Transfer Hydrogenation on the Reduction of Benzophenone $^{a}$

\begin{tabular}{clcc}
\hline entry & catalyst $(\mathrm{mol} \%)$ & yield $(\%)$ & TOF $^{b}$ \\
\hline 1 & 3b $(0.1)$ & 93 & 78 \\
2 & 3a $(0.1)$ & 90 & 75 \\
3 & $\mathbf{4 a}(0.1)$ & 50 & 42 \\
4 & $\mathbf{4 b}(0.1)$ & 53 & 44 \\
5 & $\mathbf{5 a}(0.1)$ & 60 & 50
\end{tabular}

${ }^{a}$ Benzophenone $(2.5 \mathrm{mmol})$, catalysts $2.5 \times 10^{-3} \mathrm{mmol}, \mathrm{KOH}(0.1 \mathrm{M})$ in isopropyl alcohol $(2 \mathrm{~mL})$ under refluxing temperature for $12 \mathrm{~h} .{ }^{b}$ TOF $=$ moles of product $/$ moles of catalyst per hour.

As we can see from Table 4, complexes $\mathbf{3 a}$ and $\mathbf{3 b}$ with

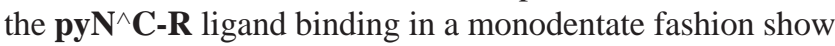
a slightly higher catalytic activity compared to their respective chelation complexes $\mathbf{4 a}, \mathbf{4 b}$, and $\mathbf{5 a}$. Nevertheless, these iridium complexes show decent activity toward the hydrogentransfer reduction of benzophenone. Under similar conditions, also noted is that the TOF in $\mathbf{3 a}$ is on the same order of magnitude as that found by Hahn et al. using a fivecoordinated iridium speces. ${ }^{16}$

The promising result on the reduction of benzophenone encouraged us to further explore the catalytic capability toward the reduction of nitroarenes. In a typical case, $p$-bromonitrobenzene, the iridium complex, solid $\mathrm{KOH}$, and isopropyl alcohol were placed in a round-bottomed flask and the mixture was heated under reflux with stirring. The progress of the reaction was monitored by thin-layer chro-

(16) Hahn, F. E.; Holtgrewe, C.; Pape, T.; Martin, M.; Sola, E.; Oro, L. A. Organometallics 2005, 24, 2203.

5784 Inorganic Chemistry, Vol. 46, №. 14, 2007 
Table 5. Reduction of $p$-Nitrobromobenzene Using Iridium Carbene Complexes ${ }^{a}$

\begin{tabular}{|c|c|c|c|c|c|c|c|}
\hline \multirow[b]{2}{*}{ entry } & \multirow[b]{2}{*}{ catalyst concn } & \multirow[b]{2}{*}[\mathrm{KOH}]{$(\mathrm{M})$} & \multirow[b]{2}{*}{ temp } & \multirow[b]{2}{*}{ time (h) } & \multirow[b]{2}{*}{$\operatorname{conv}(\%)$} & \multicolumn{2}{|c|}{ yield $^{b}$} \\
\hline & & & & & & 6 & 7 \\
\hline 1 & {$[\mathrm{Ir}(\mathrm{COD}) \mathrm{Cl}]_{2}, 6.25 \times 10^{-4} \mathrm{M}$} & 1.0 & reflux & 24 & 24 & 30 & 10 \\
\hline 2 & {$[\mathrm{Ir}(\mathrm{COD}) \mathrm{Cl}]_{2}, 2.5 \times 10^{-3} \mathrm{M}$} & 1.0 & reflux & 12 & 50 & 49 & trace \\
\hline 3 & $3 \mathbf{a}, 2.5 \times 10^{-3} \mathrm{M}$ & 1.0 & reflux & 12 & 88 & 72 & 13 \\
\hline 4 & 3a, $2.5 \times 10^{-3} \mathrm{M}$ & 0.5 & reflux & 12 & 80 & 42 & 34 \\
\hline 5 & 3a, $2.5 \times 10^{-3} \mathrm{M}$ & 0.1 & reflux & 12 & 100 & 18 & 73 \\
\hline 6 & 3a, $5.0 \times 10^{-3} \mathrm{M}$ & 1.0 & reflux & 12 & 90 & 80 & trace \\
\hline 7 & 3a, $6.25 \times 10^{-4} \mathrm{M}$ & 1.0 & reflux & 24 & 96 & 3 & $81(76)$ \\
\hline 8 & 3a, $2.5 \times 10^{-3} \mathrm{M}$ & 1.0 & $\mathrm{rt}$ & 12 & 69 & 64 & 0 \\
\hline 9 & $\mathbf{3 b}, 2.5 \times 10^{-3} \mathrm{M}$ & 1.0 & reflux & 12 & 60 & 14 & 40 \\
\hline 10 & $4 \mathbf{b}, 2.5 \times 10^{-3} \mathrm{M}$ & 1.0 & reflux & 12 & 96 & 86 & 6 \\
\hline 11 & $4 a, 2.5 \times 10^{-3} \mathrm{M}$ & 1.0 & reflux & 12 & 98 & $89(81)$ & 3 \\
\hline 12 & $5 \mathbf{a}, 2.5 \times 10^{-3} \mathrm{M}$ & 1.0 & reflux & 12 & 98 & (73) & trace \\
\hline
\end{tabular}

${ }^{a}$ Reaction conditions: nitrobenzene $(0.1 \mathrm{mmol})$, catalyst, and $\mathrm{KOH}$ in isopropyl alcohol $(4 \mathrm{~mL}) .{ }^{b} \mathrm{NMR}$ yield, isolated yields given in parentheses.

matography. After completion, followed by the usual workup procedures on the reaction mixture, aniline was produced, accompanied by the corresponding azo product (eq 2). Accordingly, a survey on a representative reduction of 4-bromonitrobenzene with various iridium complexes was carried out, and the results are listed in Table 5.

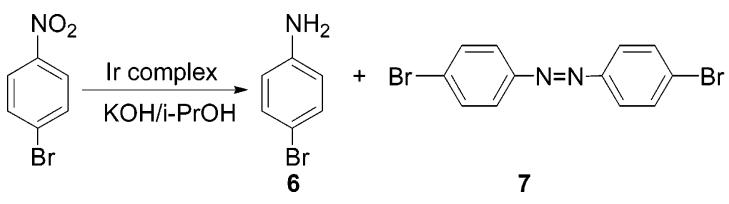

As shown in the Table 5, the conversion is faster for the iridium carbene complexes $\mathbf{3} \mathbf{- 5}$ as compared to $[\operatorname{Ir}(\mathrm{COD})$ $\mathrm{Cl}]_{2}$, with more than $80 \%$ conversion after $12 \mathrm{~h}$ under refluxing conditions. There is no significant difference in activity among all iridium complexes under similar conditions. The concentration of the base and catalysts, however, could affect the selectivity of the products. Increasing the base concentration resulted in a higher amount of the reduction product 6 . On the other hand, the amount of the azo product 7 increased with the use of a lower concentration of $\mathrm{KOH}$ (see Table 5, entries 3-5). In principle, the catalytic path toward reduction over the formation of the azo compound 7 could be achieved if we carried the reaction under a higher dosage of catalyst (entry 6). When the reaction was carried out under a diluted concentration of the catalyst, the azo compound 7 was obtained predominately (Table 5, entry 7). This is probably attributable to the dominant metalcatalyzed hydrogen-transfer reduction, namely, that the higher concentration of catalyst favors the reduction path. The iridium complex $\mathbf{3 a}$ is less active when carrying out the reduction at room temperature, with only $69 \%$ conversion over $12 \mathrm{~h}$ but with higher selectivity for providing solely the reduction product.

The reduction steps of nitrobenzene leading to aniline are quite complex. A generally accepted mechanistic pathway is depicted in Scheme 3, in which the aniline can be obtained via either the direct reduction or the condensation followed by reduction; ${ }^{17}$ the latter route is favorable under the basic conditions. In this work, the iridium carbene complexes are

(17) Blaser, H.-U. Science 2006, 313, 312.
Scheme 3

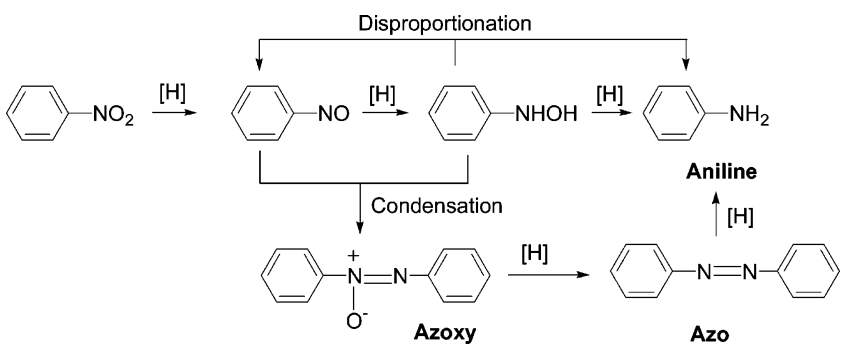

found to play a key role in the reduction of aromatic nitro compounds via a catalytic transfer hydrogenation similar to that for the reduction of carbonyl functionality. The higher concentration of $\mathrm{KOH}$ increases the concentration of isopropoxide, which further accelerates the ligand substitution on the metal center. The net result speeds up the $\beta$-elimination and the reduction process to yield the aniline product. Under a lower concentration of the catalyst, the basecatalyzed condensation of nitroso and hydroxyamine intermediates becomes the major pathway, yielding predominately the azo compound (Table 5, entry 7).

Under a similar reduction condition, we found that the iridium carbene complex catalyzes the reduction of the azo compound to aniline in a very slow manner, with less than $10 \%$ of the azo compounds converted into aniline by the use of 3a, the result of which explains why the azo compound can be obtained as the major product.

Hydrogen-transfer reductions of various nitroarenes in the presence of catalytic amounts of iridium carbene complexes were carried out under the same reaction conditions as those described for the reduction of $p$-bromonitrobenzene, and the results are summarized in Table 6 . All instances provide good yields of the desired product except when $p$-nitrophenol and 2-chloropyridine were used. It is noticed that the iodo group is largely replaced by hydrogen in the reduction of 2-iodo4-nitroaniline (entry 5). Catalytic hydrogen-transfer reduction of 2-chloropyridine resulted in the formation of bis(6isopropoxypyridin-3-yl)diazene in poor yield (18\%), indicating that the chloride in the pyridine ring was replaced by isopropoxide.

In summary, we have successfully prepared iridium pyridinyl $\mathrm{N}$-heterocyclic carbene complexes and studied their 
Table 6. Hydrogen-Transfer Reduction of Nitroarenes ${ }^{a}$

\begin{tabular}{|c|c|c|c|c|c|}
\hline entry & substrate & Catalyst, [Cat.] & base & time & $\begin{array}{l}\text { products and yield }^{\mathrm{b}} \\
\text { aniline product }\end{array}$ \\
\hline 1 & $\mathrm{Br}-$ & $\begin{array}{l}\text { 4a, } 2.5 \times 10^{-3} \mathrm{M} \\
\text { 3a, } 6.25 \times 10^{-4} \mathrm{M}\end{array}$ & $\begin{array}{l}{[\mathrm{KOH}] 1.0 \mathrm{M}} \\
{[\mathrm{KOH}] 1.0 \mathrm{M}}\end{array}$ & $24 \mathrm{~h}$ & $\begin{array}{cc}p-\mathrm{BrC}_{6} \mathrm{H}_{4} \mathrm{NH}_{2} & p-\mathrm{BrC}_{6} \mathrm{H}_{4} \mathrm{~N}=\mathrm{NC}_{6} \mathrm{H}_{4} \mathrm{Br}-p \\
89 \%(81 \%) & 3 \% \\
3 \% & 81 \%(74 \%)\end{array}$ \\
\hline 2 & $\mathrm{MeC}$ & $\begin{array}{l}4 \mathrm{a}, 2.5 \times 10^{-3} \mathrm{M} \\
4 \mathrm{a}, 6.25 \times 10^{-4} \mathrm{M}\end{array}$ & $\begin{array}{l}{[\mathrm{KOH}] 2.0 \mathrm{M}} \\
{[\mathrm{KOH}] 1.0 \mathrm{M}}\end{array}$ & $\begin{array}{l}12 \mathrm{~h} \\
12 \mathrm{~h}\end{array}$ & $\begin{array}{lc}p-\mathrm{MeOC}_{6} \mathrm{H}_{4} \mathrm{NH}_{2} & p-\mathrm{MeOC}_{6} \mathrm{H}_{4} \mathrm{~N}=\mathrm{NC}_{6} \mathrm{H}_{4} \mathrm{OMe}-p \\
100 \%(97 \%) & \\
\text { trace } & 89 \%(82 \%)\end{array}$ \\
\hline 3 & & $\begin{array}{l}\text { 4a, } 2.5 \times 10^{-3} \mathrm{M} \\
3 \mathrm{a}, 6.25 \times 10^{-4} \mathrm{M}\end{array}$ & $\begin{array}{l}{[\mathrm{KOH}] 2.0 \mathrm{M}} \\
{[\mathrm{KOH}] 0.1 \mathrm{M}}\end{array}$ & $\begin{array}{l}12 \mathrm{~h} \\
12 \mathrm{~h}\end{array}$ & $\begin{array}{cc}0 & \\
74 \% & 8 \% \\
0 \% & 66 \%(54 \%)\end{array}$ \\
\hline 4 & $\mathrm{H}$ & $4 a, 2.5 \times 10^{-3} \mathrm{M}$ & {$[\mathrm{KOH}] 2.0 \mathrm{M}$} & $12 \mathrm{~h}$ & $\begin{array}{l}p-\mathrm{H}_{2} \mathrm{NC}_{6} \mathrm{H}_{4} \mathrm{NH}_{2} \\
(100 \%)\end{array}$ \\
\hline 5 & & $\begin{array}{l}4 \mathrm{a}, 2.5 \times 10^{-3} \mathrm{M} \\
4 \mathrm{a}, 2.5 \times 10^{-3} \mathrm{M}\end{array}$ & $\begin{array}{l}{[\mathrm{KOH}] 2.0 \mathrm{M}} \\
{[\mathrm{KOH}] 1.0 \mathrm{M}}\end{array}$ & $\begin{array}{l}12 \mathrm{~h} \\
12 \mathrm{~h}\end{array}$ & $\begin{array}{cc} & p-\mathrm{H}_{2} \mathrm{NC}_{6} \mathrm{H}_{4} \mathrm{NH}_{2} \\
20 \% & 71 \% \\
0 \% & (100 \%)\end{array}$ \\
\hline 6 & & $4 a, 2.5 \times 10^{-3} \mathrm{M}$ & {$[\mathrm{KOH}] 2.0 \mathrm{M}$} & $12 \mathrm{~h}$ & No reaction \\
\hline 7 & & $4 \mathbf{a}, 2.5 \times 10^{-3} \mathrm{M}$ & {$[\mathrm{KOH}] 1.0 \mathrm{M}$} & $12 \mathrm{~h}$ & $\mathrm{Pri}_{(18 \%)}$ \\
\hline 8 & & $4 a, 2.5 \times 10^{-3} \mathrm{M}$ & {$[\mathrm{KOH}] 1.0 \mathrm{M}$} & $12 \mathrm{~h}$ & $99 \%(96 \%)$ \\
\hline
\end{tabular}

\footnotetext{
given in parentheses.

coordination behaviors. Compared to the carbene donor, the pyridinyl nitrogen donor is more labile and is readily replaced by acetonitrile. The prepared iridium complexes have shown salient catalytic activity upon hydrogen-transfer reductions of carbonyl and nitro functionalities. More importantly, these studies explore a great potential for the selective reduction of nitroarene to aniline derivatives or azo compounds. The results should attract a broad spectrum of interest in the fields of organometallics and catalysis.
}

${ }^{a}$ Reaction conditions: substrate $(1 \mathrm{mmol})$, catalyst, and $\mathrm{KOH}$ in isopropyl alcohol $(4 \mathrm{~mL})$ under refluxing temperature. ${ }^{b} \mathrm{NMR}$ yield, isolated yields

Acknowledgment. We thank the National Science Council for financial support (Grant NSC95-2113-M-002-038).

Supporting Information Available: Complete description of the X-ray crystallographic structure determination of $\mathbf{2 a}, \mathbf{3} \mathbf{b}$, and $\mathbf{5 b}$ including tables of atomic coordinates, isotropic and anisotropic thermal parameters, and bond distances and angles provided as CIF files and spectral data of reduction products. This material is available free of charge via the Internet at http://pubs.acs.org.

IC070330L 